\title{
Chapter One \\ Born in the Crucible of War Chapaev and His Socialist Realist Comrades
}

In life there is always a place for feats.
В жизни всегда есть место подвигу.

-Boris Polevoi

Heroism means doing the impossible.

Геройство-это значит совершить невозможное.

-Fyodor Gladkov

When Maxim Gorky published his novel Mother in 1906, it became a prototype for future socialist realist novels. Over a quarter of a century later, when in 1934 the method of socialist realist writing was codified, Mother was listed as an officially approved exemplar. Sitting at an estate in the Adirondacks, ${ }^{1}$ Gorky had written the novel in the wake of devastating events in Russia: the humiliating defeat in the Russo-Japanese War and the convulsions of the 1905 revolution that failed to bring the tsarist state down. This must have seemed to Gorky like a "plastic juncture," to use John Dewey's term, though that assessment turned out to be premature. His novel Mother was in its own way a war novel that confronted the working class problems of Russia and heralded the coming Revolutions.

After a brief discussion of Mother, we look in this chapter at two of its progeny, two of the most significant novels to emerge in the immediate aftermath of the Revolution and Civil War. Dmitry Furmanov's Chapaev appeared in 1923, and Fyodor Gladkov's Cement was published two years later. ${ }^{2}$ Vasily Chapaev is pictured in the heat of the Civil War, while Gladkov's Gleb Chumalov has returned home to a destroyed and abandoned factory after his time

1 Barry Scherr, "Gorky and God-Building," 189-210, in William James in Russian Culture, ed. Joan Delancey Grossman and Ruth Rischin (Lanham, MD: Lexington Books, 2003), 189-190.

2 Dmitrii Furmanov, Chapaev (Moscow: Gosizdatel'stvo khudozhestvennoi literatury, 1961). This text uses volume 1 of Furmanov's Sobranie sochinenii v chetyrekh tomakh (Moscow: Goslitizdat, 1960). The first edition of Gladkov's Cement was printed in Krasnaia nov' (1925) nos. 1-6, but unless otherwise noted, I will be quoting from the English translation of that edition, A. S. Arthur and C. Ashleigh, trans., Cement (New York: Frederick Ungar, 1980). 
fighting the White Army. ${ }^{3}$ These characters represent two possible models of heroism, Russian men fighting for the future in the war and afterward on the economic front. Although the post-Civil War reconstruction work Gleb does in Cement is also heroic, it is Chapaev's heroism that little boys dream of.

Both novels were enormously popular with contemporary readers. ${ }^{4}$ Though Chapaev and Cement were written before the codification of socialist realism, they too wound up as official exemplars of the method. Unlike the characters in Mother, the heroes in these novels are soldiers, and war figures centrally as a marker of what is heroic about them. Both were based in part on the experiences of their authors and include autobiographical details. Both novels also feature a conflict between the spontaneous hero who emerges from the people and the more conscious party figure. ${ }^{5}$

Between them, Gorky, Furmanov, and Gladkov attempted to reconfigure the Russian literary hero in the revolutionary period, placing him in conflict with the state, with external enemies, and with internal enemies. Chapaev proved to be the most enduring.

\section{Gorky, Mother, and the Birth of the Socialist Realist Hero}

Maxim Gorky (1868-1936) was a writer from the "lower depths." In the convulsions and revolutionary ferment of the early twentieth century, as the tsarist empire began to wane, he stepped onto the public stage.

3 Robert Busch notes that the focus on the economic front is new in 1925; in Soviet fiction up to this point the civil war had been the predominant theme. See Robert Busch, "Gladkov's Cement: the Making of a Classic," SEEJ 22.3 (1978): 348-361, esp. 348-349. This article follows the evolution of the novel from its original publication in 1925 in Krasnaia nov' until the time of Gladkov's death, as it conformed to the changing norms of Socialist realism. See also Maurice Friedberg, "New Editions of Soviet Belles-Lettres: A Study in Politics and Palimpsests," American Slavic and East European Review, 13.1 (Feb. 1954): 77-88 and L. N. Smirnova, "Kak sozdavalsia Tsement," in Tekstologiia proizvedenii sovetskoi literatury: Voprosy tekstologii 4 (1967): 140-227.

4 On this, see Evgeny Dobrenko, The Making of the State Reader (Stanford: Stanford University Press, 1997), 130-131. Also Osip Brik, "Pochemu ponravilsia “Tsement," Na literaturnom postu, 2 (1926): 30-32, and Valer'ian Polianskii, “Tsement i ego kritiki," in Na literaturnom postu 5-6 (1926): 50-53. Brik reacted negatively to Chumalov, and we will see why below.

5 Historically Furmanov and Gladkov have been linked as two proletarian writers first published by Krasnaia nov'. Indeed, when Alexander Voronsky was dismissed from the editorship of Krasnaia nov', purportedly for denying proletarian writers access to the journal, he replied that "he had always been willing to publish proletarian writing of quality, such as that of Furmanov and Gladkov." See A. Kemp-Welch, Stalin and the Literary Intelligentsia, 1928-1939 (Basingstoke: Macmillan, 1991), 42-44. 
A Romantic and a product of the nineteenth century, Gorky believed in the idea of the Great Man, a hero in Carlyle's terms, and the fact that he sought that Great Man among the common people-and moreover through the exigencies of his own biography came to be seen as that Great Man-was only one of the conundrums of his work and life. ${ }^{6}$

The putative father of Soviet literature, Gorky in his 1901 "Song of the Stormy Petrel" ("Pesnia o burevestnike") drew on Romantic tropes of the nineteenth century.7 In the song, other birds (the gull, the loon) fear the coming storm, but the petrel earns the appositives "demon of the storm" and "prophet of victory" and yearns for rough weather. No fear.

Interpreters then and now saw revolution in that storm at sea, and in the stormy petrel, a harbinger of change. Like Mikhail Lermontov's sailboat-in his 1841 poem "A Lonely White Sail Gleams" ("Beleet parus odinokii")-the petrel actively seeks a storm. But while Lermontov's hero imagines that in that storm he would find peace, Gorky's here seeks "life's battle." 'Throughout much of Soviet history, Gorky himself was figured as a Romantic hero, a "stormy petrel" who welcomed and heralded the approaching storm, ${ }^{9}$ and he

6 Gorky has been the subject of several new biographies in Russia; Pavel Basinskii published a ZhZL biography in 2005, Viktor Peteli published Zhizn' Maksima Gor'kogo (Moscow: Tsentrpoligraf, 2007), and Dmitrii Bykov wrote Byl li Gor'kii, a fuller version of his Channel 5 documentary film, in 2008 (Moscow: AST, Astrel', 2008). A new English translation of his classic Childhood (translated Graham Hettlinger, Chicago: Ivan Dee, 2010) may get him more attention in the United States in the next decade as well.

7 The "Song of the Stormy Petrel" is sung by a siskin in the story "Spring Melodies," a short tale about birds in springtime. The censorship forbade the tale itself, but "Song of the Stormy Petrel" was allowed for publication in the April 1901 issue of Zhizn'. Maxim Gorky, Sobranie sochinenii v tridtsati tomakh, vol. 5 (Moscow: Khudozhestvennaia literatura, 1950), 322-327: "Song" on 326-327; notes and commentary 482-486.

8 Lenin adopted the last line of the "Song," ending his own article "Before the Storm" with the words "Let the storm come more fiercely!" See Gorky, volume 5: 485, citing V. I. Lenin, Sochineniia, 4th ed., vol. 11, 117.

9 In a 1999 documentary novel about Gorky, Arkady Vaksberg uses the metaphor of the "stormy petrel" for Gorky himself. See Gibel' burevestnika: Maksim Gor'kii, poslednie dvadtsat' let (Moscow: Terra-Sport, 1999). Vaksberg believes that his documentary novel replaces mythical approaches to the man that were an inherent part of all previous biographies of Gorky, but he uses the revolutionary romantic image of the burevestnik anyway, underscoring the ways in which Gorky's myths and life are mutually inextricable. On the reassessment of the "Gorky Myth," see Andrew Barratt and Edith W. Clowes, "Gor'ky, Glasnost' and Perestroika: The Death of a Cultural Superhero?," Soviet Studies 43, 6 (1991): 1123-1142. 
worked hard to fashion and be true to that image. As Vladislav Khodasevich recalled in his 1936 memoir essay about Gorky, by the 1920s Gorky felt that any potential course of action must be subsumed to his image. Sometimes he told Khodasevich that he had an urge to act in unexpected ways, but he chose not to. "It's impossible. I would damage my biography," he would say. ${ }^{10}$ His effective management of his image enabled Soviet commentators to praise Gorky as a prophet of revolution, though Gorky well understood the horrors and dangers of warfare.

In the phenomenon of the First World War-like his American counterpart Randolph Bourne-Gorky saw a loss of culture, a decline in humanity that foretold a future of violence against which he felt compelled to struggle. In January of 1917, Gorky shared with French writer Romain Rolland an idea that would bring back a "voice of Dante" to speak to Russians of all ages:

We adults, who are fated to abandon this world in due time-we will leave our children a pathetic inheritance, we are bequeathing them a very sad life. This absurd war is stunning proof of our moral weakness, of the decline of culture. Let's remind our children that people were not always as weak and wicked as-alas! - we are now; let's remind them that all nations had-and have now-great people and noble hearts! It is essential that we do this precisely in our days of victorious cruelty and brutality. ${ }^{11}$

According to Gorky, a true hero complete with a heroic voice was precisely what Russia needed in the twentieth century. Gorky proposed the Lives of Remarkable People (Zhizn'zamechatel'nykh liudei), a series of biographies that were to present "great people and noble hearts" to readers, grounding them in a romantic worldview that would enable them to become citizens of the world and of their own nation and that would counter the brutalities

10 “Нельзя. Биографию испортишь" (372). Khodasevich was in fairly close contact with Gorky from 1918 through 1925, what he would call "personal, not business or literary” relations (354). See Khodasevich, “Gor'kii," Koleblemyi trenozhnik (Moscow: Sovetskii pisatel', 1991), 353-374.

11 A. M. Gorky, "Letter to Romain Rolland," in Sobranie sochinenii v tridtsati tomakh, vol. 29 (Moscow, 1955), 374-375. Gorky's relations with Rolland, and the latter's disappointment in 1935 when he visited Moscow and discovered that Gorky had become part of the "privileged class," are fascinating, though not relevant to the present discussion. See Voprosy literatury 3 (1989): 239-240. 
of world war, militarization, famine, and suffering. The Lives series finally got off the ground in 1933, publishing seventeen volumes in its first year, including a biography of Italian poet Dante Alighieri. It continues publishing to this day. ${ }^{12}$

In his fiction and in his life, Gorky consciously set out to create a new kind of protagonist for the society from which he himself had emerged, one who could function as a hero for the proletariat. He does this twice over in his classic novel Mother. ${ }^{13}$ The events of Mother transpire during a time of social unrest, although Gorky does not mention any actual war in the narrative. Nonetheless, the situation he chronicles is one of class war and underground revolutionary activity, as representatives of the workers struggled with the authorities and the factory owners to promote their desires for access to learning and power.

In this revolutionary novel, we can trace the origins of the Soviet war hero. After the Revolution, literature drew on the activist-heroes who peopled novels such as Gorky's, and the towns and factories of Soviet life served as the stage for the conflicts of a militarized society, between retrograde elements such as Christians, tsarists, and individualists and the newly collectivist state. Novels such as Gorky's Mother (Mat') and Fyodor Gladkov's Cement (Tsement, 1925) presented the creation of the new protagonist as a part of the revolutionary project—related to, in some cases presaging, and stemming from actual war. The relationship between the creation of this social hero and the Romantic roots of the Russian literary hero (and often his creator) can be seen clearly in Maxim Gorky himself.

12 In 2010 a new volume was published on exiled writer Sergei Dovlatov-an interesting addition to the pantheon of twentieth-century "Remarkable Lives." In 1931 Gorky headed up a different series: "History of the Civil War." With this work he hoped to keep the heroic efforts of the Red Army soldiers alive for their descendents; the participants in the Civil War themselves were to research and write the books "with maximal simplicity, clarity and truthfulness." See "To the Participants of the Civil War," Sobranie sochinenii v tridtsati tomakh, vol. 26, 116-119, quote on 117. For details about the plan, see Gorky's letter to Stalin of November 27, 1929, translated in Maksim Gorky: Selected Letters, ed. Andrew Barratt and Barry P. Scherr (Oxford: Clarendon Press, 1977), 319-320. Two volumes of what were to be books for peasants "to be read like a novel" were published in 1937 and 1942. For more on the Civil War series, see Hartzok, Children of Chapaev, 2009, chapter 4.

13 First published in English in an American edition of 1907, the novel was revised, shortened, and made more concise in its Russian publication. See Scherr, Maxim Gorky, 43-45. 
When Gorky chose the title for Mother, he had a number of things in mind. The novel features a proletarian protagonist named Pavel Vlasov, who gets arrested in the first part of the novel and by the end is sent into exile in Siberia. Pavel's mother, initially a conservative and timid woman who focuses inward on her personal family, is transformed over the course of the narrative to become a true "mother" to the movement. Her Christian devotion to the church and God is also transformed into a belief in something larger-a struggle for change on this earth to benefit all. By naming the novel after his secondary character, the mother Nilovna (called, moreover, by her patronymic rather than her given name), Gorky offers a generative model for future revolutionary action. As Barry Scherr has written, these two characters, the son and the mother, are "revolutionary archetypes," representing their respective generations: the generation of the son-revolutionary-and that of the parents destined to join their offspring. ${ }^{14}$ "Mother" with a capital $M$ defines Gorky's attitude toward revolution: not only can the older generation be reformed, but they can "give birth" to more and more youth willing to work and fight for changes in society.

What Scherr identifies as the "myth of the revolutionary spirit" is contagious, and it penetrates generational boundaries in unexpected ways, counteracting the biological assumption that a mother gives birth to a son. Here instead, the son Pavel reverses genealogy and passes his legacy on to his mother, who inherits his comrades and the movement he loves. A mother is a generative figure, and Gorky uses the metaphor of the family to indicate that though beyond her reproductive years, Nilovna can continue to have children and to bring more and more of them into the larger revolutionary "family." Thus Gorky harnesses the instincts of the mother to a larger cause and demonstrates how she can exchange her loyalty to a "personal" family for loyalty to the larger social family.

What's more, Gorky's "mother" is presented as a kind of metamother. In the novel, we hear one of Pavel's comrades say to her, "You, mother, are capable of a great deal. You have a great capacity for motherliness!"15 This is her main characteristic. Not a woman, really, or even an individualized person; we never find out her first name, for example, but continue to think of her as the other characters do, with the class-based habit of calling people by their

14 Scherr, Maxim Gorky, 44.

15 Maksim Gor'kii, Mat' (Leningrad: Khudozhestvennaia literatura, 1986); Maxim Gorky, Mother (Secaucus, NJ: Citadel, 1972), 97. 
patronymic. Nilovna is rather motherhood personified and indeed amplified beyond her personal status. As we follow Nilovna's speeches throughout the novel, we see that family is paramount for her, and instead of losing a son when Pavel is arrested, she gains an entire generation of sons and daughters, a fact demonstrated by her frequent use of child metaphors. ${ }^{16}$

As she comes to realize what her son's comrades are up to, she feels concern for them as an adult observing children who do not understand the significance of their actions:

The mother felt that she knew the life of the workingmen better than these people and saw more clearly than they the enormity of the task they assumed. She could look upon them with the somewhat melancholy indulgence of a grown-up person toward children who play man and wife without understanding the drama of the relationship. (Gorky, Mother, 244)

Later in the novel, she begins to feel the ties of family for Pavel's comrades, though she has trouble at first with the vocabulary to express herself. When Rybin-a broad-shouldered, black-bearded peasant who has been converted to Pavel's cause-is arrested, Nilovna at first describes this neighbor as a stranger to her, "chuzhoi," but this doesn't feel right. She then brings him into her family with a simile: "I respect him like a brother-an elder brother" ("uvazhaiu kak rodnogo brata-starshego," 305), but that is not quite right either. Ultimately, she comes to embrace her role as mother to all, as the narrator tells us, "Her heart beat tenderly with 'My dears, my children, my own"” (“Deti! Rodnye moi!" 341).

Gorky's mother begins her road to consciousness spontaneously, as the "disciple" in the "mentor/disciple" pattern should. She feels that "deep inside her, words were being born, words of a great, all-embracing love." (188) Somewhat later, she comes to understand the importance of words: "Perhaps in our day a word is worth more than a person." (312) Gradually, she moves from pure emoting to articulating the truth (as we are told, the "word is born" in her [rozhdaetsia slovo]). By the end of the novel, she speaks, and her words are worth heeding: "You are in truth comrades all, kinsmen all, for you are all children of one mother, of truth. Truth has brought you forth; and by its power you live!" (393)

16 On Gorky's use of the term "comrade," see Borenstein, Men without Women, 286, n. 46. 
In Gorky's transformative narrative, a spontaneously good woman must become conscious (and know the truth) and must spread that consciousness (and thus speak the truth). This process is facilitated by exposure to the best influences, such as those of Pavel Vlasov and his revolutionary circle. Truth itself, as is obvious in the Russian, is feminine, Pravda - an archetypal mother of the comrades Nilovna addresses. As she endures the beating she receives at the end of the novel-the ambiguous scene that leaves the reader uncertain whether she perishes or merely succumbs to unconsciousness, to rise anew another day-we see her kinship with the people. Though she is beaten and down, "her eyes did not fade and they saw many other eyes-those [eyes] burned with the brave, piercing fire so familiar to her-the fire that was dear to her heart" ("rodnym ee serdtsu ognem," 401).

Although the Vlasovs (mother and son) and their comrades are fighting the state, they are in the process creating their own symbols and touchstones of national spirit: the red banner held up by the revolutionaries, the notion of Truth as a rallying point in the struggle with the tsarist regime, the "fiery eyes" that hold kinship within them.

Mother is built on three symbolic paradigms: the "family" spirit the comrades find in Nilovna after she has ascended to revolutionary mother status; Pavel's teaching his mother to understand and view the world in a wider, more communal sense; and the martyred son who will go into exile and perhaps return one day. ${ }^{17}$ But Gorky's doubled characters in Mother set up yet another pattern for Soviet fiction: Nilovna is the true protagonist of the novel, and by picking up the banner dropped by her son, she symbolically takes on his embattled position vis-à-vis the state.

This militarization of life through revolutionary struggle-with its secret cells, its comradely spirit, its ideological leaders, its foot soldiers, and, most importantly, its enemies-transformed the literary protagonist into a military hero. Nilovna, the Mother, became a touchstone in the new protoSoviet nationalism, a sign that members of the older, conservative generation were capable of change and of unity with the younger generation. In the novel we see Pavel Vlasov recruit and train his own mother to his cause. The mother brings new qualities to the concept of heroics, with her maternal instincts, her gentle nature, and her ability to become firm once she too believes.

17 See Clark, The Soviet Novel: History as Ritual. 
Gorky planned to write a sequel to this novel, entitled Son, in which Pavel Vlasov would have returned from exile to continue his work. The fact that he did not do so leaves Nilovna in a powerful position: the legatee of revolutionary dreams, the meek woman celebrated in the title of the novel, grown larger than life. Eponymous women in Russian literature before her included Leo Tolstoy's Anna Karenina, the tragic adulterous noblewoman; Nadezhda Durova's autobiographical Cavalry Maiden (Kavalerist - devitsa), again a noblewoman, cross-dressing to find her place in a male military world; or Anton Chekhov's "The Darling" ("Dushechka", 1898), who took on the characteristics of all the men around her but had no essence of her own. Nilovna is grounded, thoughtful-puzzling out relationships and new vocabulary and attitudes when they are not immediately clear to her-and most importantly a member of the lower peasant/proletarian classes, the classes who would inherit Russia after the Revolution. She is a new woman.

Nilovna occupies the niche of Mother of the Revolution and Mother of Socialist Realism with a quiet fortitude. However, she did not rise to the stature of a hero in Carlyle's sense, nor did she prove a lasting Soviet heroine. Perhaps because she was a woman and a mother, or perhaps because the crucial war context was missing in her creation and development, Nilovna remained a part of the pre-Soviet past. She did not capture the imagination of Russian writers seeking to found new generations of heroes. That role belonged to Chapaev.

\section{From Life to Myth: Furmanov Creates Chapaev}

This book takes its title from both the hero Chapaev and the "Chapaev text" of Soviet literature because Chapaev looms so large in the Soviet imagination. In the years since the novel was published in 1923, Chapaev's name and image have been evoked in virtually every war narrative that has followed, and many other narratives besides, especially fiction about children and their development. To reiterate, playing Chapaev and Reds versus Whites became the Soviet child's version of cops and robbers or cowboys and Indians. ${ }^{18}$

18 In his Folklore for Stalin, Frank Miller describes the many pseudo-folk songs and folk poems that emerged as part of the "Chapaev text." These celebrations of key moments in Chapaev's history were prototypes for the popular series of anecdotes that satirized the heroic Chapaev. See Frank Miller, Folklore for Stalin: Russian Folklore and Pseudofolklore of the Stalin Era (Armonk, NY: M.E. Sharpe, 1990), and Seth Graham, Resonant Dissonance: The Russian Joke in Cultural Context (Evanston: Northwestern University Press, 2009). See also Hartzok, Children of Chapaev, 2009. 
For the novel, Furmanov drew much of his ideological underpinning from the polemics of the 1860s and categories used by his predecessors Dostoevsky, Chernyshevsky, and Ivan Turgenev: Furmanov characterized Chapaev as a person who "love[d] strong, decisive, firm words. And he loved decisive, firm and intelligent actions even more!" 19 Words and deeds-these conflicting dichotomous categories tortured nineteenth-century literary heroes from Turgenev's Rudin and Bazarov to Dostoevsky's Raskolnikov. Furmanov harnessed them together in his novel in order to try and pull the peasantry into a conscious future.

Furmanov himself was thinking about issues of heroism in war in 1919, as he fought side-by-side with the real Chapaev in the Civil War. In an essay from that year, "Conscious Heroes," Furmanov explained the difference between a mere "brave person" (khrabrets) and a hero: "The heroism of communists inevitably emerges from their deep conviction of the righteousness of their cause. They are firm and manly, passionate and decisive. They are staunch and calm, for they have consciously entered into the struggle." ${ }^{20}$ Spontaneity and elemental energy are hallmarks of bravery. Passionate, decisive, manly action bolstered by awareness of the cause and conscious struggle-this is how Furmanov defines heroism, and these are the characteristics of the new Soviet hero. As we discussed in the last chapter, Soviet heroism-both in war and in peacetime-equals bravery plus consciousness.

Dmitri Furmanov was born in 1891, the third child of a displaced peasant, and he personally saw the 1905 worker strikes in Ivanovo-Voznesensk at an impressionable age. Indeed, he was witness to the very type of strikes and demonstrations described in Gorky's novel Mother. The young Furmanov became fascinated with ideas of anarchy and dreamed of joining in the action of overthrowing bureaucrats and administrators. The admiration the novelist would express for Chapaev, whom he called a "horse of the steppes," came in part from that adolescent experience of watching adults rebel against the controls that impeded their freedom.

As a young man, Furmanov imagined himself becoming a writer and chronicled his hopes in his diary. "Before me," he wrote, "I can see my future literary life - not as formidable and turbulent as those of Belinsky, Pisarev and Dobrolyubov, but nonetheless a wonderfully fruitful one." Furmanov's early

19 Furmanov, Chapaev, 156 [emphasis mine].

20 Dmitrii Furmanov, Nezabyvaemye dni, in the series Biblioteka molodogo rabochego (Leningrad: Lenizdat, 1983), 205-06. 
thoughts on the role of writers and critics and the meaning of art were very much related to the "word and deed" debates of Turgenev and Chernyshevsky: against "art for art's sake." Furmanov believed that art must have a purpose, a goal, and for him that goal was engendered by what he called "holy acts."

As the First World War broke out, Furmanov tried to figure out whether war could create a new society, whether this war was a just war. Speaking out at a prowar rally at Moscow State University, Furmanov compared the current war to the War of 1812. "Is war ruinous or beneficial?" he asked. "One cannot answer this question with certainty, without knowing what kind of war we're speaking about; everything depends on circumstances, time, and place. The War of 1812 was salutary for the Russian people. But what about this war? Will it be good for the people?"21 Soon after this outburst, Furmanov had the opportunity to find the answer himself: he joined the war effort, first as a medical orderly, and by 1915 as a war correspondent. He joined the Bolsheviks but continued to write about his experiences of war: "Grey Heroes," "Medical Assistants," "The Death of a Pilot." These war sketches, most of which remained unpublished, served as raw material and practice for the future novelist of the Civil War.

Furmanov returned to Ivanovo-Voznesensk in 1917 to do propaganda work among the textile workers and the new local Soviet of Workers' and Soldiers' Deputies. By August of 1917 Furmanov had become one of the main leaders of the Ivanovo Soviet, and on October 25 it was his phone call to Izvestiia in Moscow that brought the news of the Bolsheviks taking power to Ivanovo. On that day, Furmanov was appointed chairman of the Provisional Revolutionary Headquarters of Ivanovo-Voznesensk. His status as a provincial political leader continued to rise throughout 1918, and in February of 1919 he became the political commissar of Chapaev's forces.

Furmanov based the novel Chapaev on the few months he served as commissar with the Twenty-fifth Division, between March and August of 1919, after which he was transferred to the Turkestan front. "There were many talented, brave, charming commanders in the civil war era. Chapaev was lucky," wrote Yury Libedinsky, "that Furmanov was assigned to him."22

21 Aleksandr Isbakh, Furmanov, in series Zhizn'zamechatel'nykh liudei (Moscow: Molodaia gvardiia, 1968), 42.

22 Yury Libedinsky, "Bol'shevik, voin, pisatel'," Furmanov v vospominaniiakh sovremennikov, ed. A. Isbakh and D. Zonov (Moscow: Sovetskii pisatel', 1959), 172-192; quote on 185. 
A regional critic from Ivanovo-Voznesensk called Chapaev Furmanov's "hymn in honor of the Bolshevik textile workers of Ivanovo" and maintained that this novel was also a "hymn to the Party." ${ }^{23}$ In fact, of course, Furmanov was lucky to have been assigned to the historical Chapaev. In the end they made each other's reputation.

In writing Chapaev, Furmanov participated in what LEF (Left Front of Art) critics called "a literature of fact." Furmanov's Chapaev is believable as a character precisely because he is drawn from life. But the novel becomes more credible in addition because of its "conscious" character, Bolshevik political commissar Fyodor Klychkov, who was drawn from Furmanov's autobiography. Thus in a sense Furmanov assigned the "bravery" to Chapaev and the "consciousness" to Klychkov, creating a story of heroism from his own Civil War experiences and through this staging of historical events contributing to the growth of Soviet concepts of podvig. In Chapaev, Furmanov created the new Soviet hero.

\section{Chapaev and the Historical Roots of the New Soviet Hero}

Familiar though Chapaev remains, let us take a moment to review the plot of the original novel. The action takes place on the Eastern Front, over the course of six months during the Civil War. Our hero Chapaev is a peasant serving now in the Red Army as the commander of the Stenka Razin Division. He is already an exemplary leader of men-disciplining them when necessary, instructing them to treat civilians with respect, strategizing against the Whites. His actions as a military leader would merely make him brave. What makes him heroic over the course of the novel is his evolution, his ideological growth under the tutelage of the division's political commissar Fyodor Klychkov. During the course of the Civil War, Chapaev is transformed from a peasant-soldier who fights into a Soviet soldier who fights for the right reasons. He is a brave peasant who gains consciousness to become a true military hero. This, at one level, is the most important action in the book. And at the end of the novel, the hero dies, shot while crossing a river.

It is a simple story, and part of its appeal lies in the fact that this new Soviet hero drew on models from the Russian past which would have resonated with readers at the time. As Randolph Bourne explained, in times of war "old

23 Pavel V. Kupriianovsky, Gor'kii. Furmanov. Serafimovich. A. Tolstoi (Ivanovo: Ivanovo knizhnoe izdatel'stvo: 1960). Quotes on 109 and 169. 
national ideals" are readapted by the state into "universal touchstones." The powerful image of Chapaev has its roots in and represents a continuity with nineteenth-century literary heroes in the realist tradition.

Judith Kornblatt has argued that the figure of Chapaev, as presented by novelist Dmitry Furmanov (and then later by filmmakers Sergei and Georgy Vasiliev), was perceived by readers and viewers as a Cossack because the creators of his myth accessed the cultural code of the Cossack in creating his character. "The harnessing of Chapaev . . may be the main theme of the entire novel," says Kornblatt. She adds, "For Furmanov and his readers, 'Cossack' had become firmly equivalent to 'mythic hero."'24 Thus Furmanov in fixing Vasily Chapaev on paper transformed the historical figure, utilizing literary ideas of the Cossack hero drawn from authors like Pushkin and Gogol, Mordovtsev and Kukolnik, and of course Leo Tolstoy.

Another reason for this may have been the prominence of the Cossack figure as an embodiment of the "Russian spirit" in iconography from the First World War. The actual Cossack Kozma Kryuchkov who fought in that war was, as Stephen Norris notes, the first soldier to be awarded a St. George's Cross. Kryuchkov had the qualities of a Russian folk hero, of a bogatyr; among other feats, he was said to have defeated eleven German soldiers single-handedly. Those alleged actions in wartime earned him more than just a medal. This Cossack became immortal, with his image reproduced in numerous prints, songs, books, even in film. ${ }^{25}$ As a Cossack war hero immortalized in celluloid, Kryuchkov's fate prefigured that of Furmanov's Chapaev.

Furmanov reached for another nineteenth-century source as well in creating the character of Chapaev-the "superman" or extraordinary man of nineteenth-century Russian fiction. Chernyshevsky's Rakhmetov in What Is to Be Done? (1862) and Dostoevsky's Raskolnikov in Crime and Punishment (1866) were two passionate and physical beings who chose to submit to discipline-asceticism in Rakhmetov's case and intellectual rigor in Raskolnikov's. Dostoevsky "breaks" Raskolnikov, having him recant and regret his intellectual pride, but his strength of character and will remain in the reader's

24 Kornblatt, Cossack Hero, 166-168.

25 Stephen M. Norris, A War of Images: Russian Popular Prints, Wartime Culture, and National Identity, 1812-1945 (DeKalb, IL: Northern Illinois University Press, 2006). See also Karen Petrone, "Family, Masculinity, and Heroism in Russian War Posters of the First World War," in Borderlines, ed. Billie Melman, 95-120 (New York: Routledge, 1998). 
mind despite his transformation in the novel's epilogue into a repentant sinner and potential lamb of God. In the Russian tradition, hagiography led to biography. Chapaev brought that tradition into the twentieth century for the Soviet state.

Thus Furmanov also participated in the wider literary phenomenon in the 1920s of combining biography and autobiography as sources for fiction. We know that readers of the time were interested in biography, in the Bildungsroman. They sought models for their own lives in contemporary heroes as well as in historical biographical fiction. Again according to Dobrenko, readers wanted "thick books, so they can describe a person's life from the cradle to the grave." In the words of one librarian:

Thick novels about everyday life attract the reader more than anything else. He doesn't want the hero to be in a hurry, or to say just a few quick phrases here and there. He wants a realistic novel, realistically written, one that solves the problems of life that concern him.

Some readers liked Chapaev for just this reason. "A good book. I like it because it's big," responded a contemporary. ${ }^{26}$

\section{From Cossack War Hero to Soviet Military Hero}

It is important not to forget that though all the topoi of the Cossack myth are present in Furmanov's novel, the historical Chapaev was no Cossack. Born in 1887, Vasily Chapaev was a real peasant from the Chuvash region. He fought as a soldier and then as a noncommissioned officer in the tsarist army during World War I and outdid Kryuchkov by receiving the Cross of St. George three times.

Late in 1917 Chapaev was elected to head an infantry regiment. But leaving his tsarist war record behind, Chapaev joined the Reds and received his own division. Fighting the armies of General Kolchak, Chapaev led his brigades on the "most crucial part of the front." ${ }^{27}$ On September 5, 1919, the forces he led were ambushed by the White Army, and Chapaev drowned in the Ural River as he tried to escape. Famed pedagogy expert Anton Makarenko, glorying in Furmanov's portrayal, proclaimed:

26 Quotes from Dobrenko, 130-31.

27 See A. Makarenko, “Chapaev D. Furmanova," Literaturnyi kritik 10-11 (1934): 102$19 ; 106$. 
Even in these deficiencies we see Chapaev's steady, admirable strength, his deep and clear humanity, his indefatigable, courageous passion for victory, his wide, open personality. Chapaev gave more than his sword for victory. He gave all of himself . . . not for the beauty of the feat (podvig), not for glory, not for moral perfection. He gave everything for the victory of the revolution, for the practical but grandiose goal of the party. (118)

Podvig was not an aesthetic or moral goal. Chapaev, in Makarenko's view, was not in the war effort for himself or for individual glory. He did it all, and was sacrificed, for the party, for the good of the collective.

The much-decorated hero of the tsarist army was transformed into a symbol of peasant know-how and revolutionary courage and martyred in the waters of Siberia. Furmanov took the rudiments of the historical biography and turned Chapaev into a model for the peasant revolutionary, the Soviet military hero. As such, his character is overtly built on his historical predecessors, leaders of peasant revolts such as the Cossacks Emelian Pugachev and Stenka Razin. In the novel, Klychkov, "consciousness" personified, strives to lead Chapaev from his inherent "spontaneous" state into that of the socialist realist positive hero. The mentor/disciple pattern is clearly visible here as Chapaev "grows" and matures over the course of the novel.

This mentoring is all the education Chapaev gets; the tragedy of the novel, in the view of Makarenko and others, is not simply that Chapaev died at the end but that he perished before having a chance at a formal education, still only dreaming of studying "algebra" (109). He learned from life, and from war, melding his natural talents with the lessons of his political commissar and his experiences in battle to help create a new Soviet culture.

In Chapaev Klychkov serves as the voice of the author, offering cultural analysis in the expository sections of the novel. Before he meets his future commander, Klychkov imagines him as "the fairytale figure of Chapaev, ataman of the steppes." As we read the section of the novel before the two protagonists meet, we essentially see how those old national ideals are transformed into new universal touchstones under the pressures of war. Klychkov muses:

He is truly a popular hero ... a hero from the camp of outlaws-Emelka Pugachev, Stenka Razin, Ermak Timofeevich ... Those men did their deeds in their own time, and this one has been given a different time- 
so he has another kind of deed ... it's clear that daring and mettle are Chapaev's main character traits. He is more of a true hero than a fighter, more a fiery adventure-lover than a conscious revolutionary. Clearly in him the elements of restlessness and thirst for new impressions are primary and unusually strong. But what an original personality against the background of the peasant insurgency, what an original, striking, colorful figure! (33)

Thus Chapaev is portrayed as a peasant in the Cossack leader model. This quote clearly demonstrates the link, for Furmanov, between the Romantic hero from the people and the Soviet military figure.

Klychkov is able to master Chapaev's "Cossack-like" skills-horsemanship and bravery in battle-much more easily than Chapaev masters Klychkov's political clarity. ${ }^{28}$ Furmanov wanted to make Chapaev's path to true Soviet heroism a difficult one, to avoid creating a "superman." In the early stages of work on his novel, Furmanov wrote, "Should I present Chapai with all his faults, his sins, with his human entrails [showing], or, as is usually done, present a fantastic figure, that is to say a striking but in some ways castrated man?" 29 He added, "I am tending toward the former [strategy]." The innovation in Furmanov's novel-sometimes forgotten now, given the legacy of the Chapaev cult-was to make his revolutionary peasant-hero human.

There was, however, a conflict in Furmanov's concept of the hero. While he still celebrates the elemental in Chapaev, he explicitly connects restraint with being cultured and considers that to be the goal for revolutionary peasants and workers. When Klychkov notices that Chapaev stands out among the other peasant-soldiers, it is precisely because "he already seemed to have a bit of culture; he did not look as primitive, did not hold himself as others did: as if a horse of the steppe was holding his own bridle in check" (61, emphasis mine). This bridle, this emblem of culture and control, represents the "rein" of consciousness over the elemental.

28 Furmanov, Chapaev (Moscow: Gosizdatel'stvo khudozhestvennoi literatury, 1961), 33. See Kornblatt: "The message is obvious, although heroic spontaneity is all fine and good, the Soviet ideal requires order. [... ] The new 'Cossack' was not unbounded but rather carefully confined by Soviet strictures” (Kornblatt, The Cossack Hero, 168).

29 Furmanov, Sobranie sochinenii v chetyrekh tomakh, vol. 4 (Moscow: Goslitizdat, 1961), 285, cited in M.N. Sotskova, Dmitrii Furmanov (Moscow: Prosveshchenie, 1969), 44. 
The political commissar Klychkov gives a running commentary in the novel that explains the process of transformation as he watches it unfold. Although he almost idolizes Chapaev for his iconic and mythical behavior, he struggles with the definition of "hero." Consciousness is the prerogative of the workers, not accessible to the "spontaneous" peasant character, but that cannot take away from Chapaev's heroic traits. "Chapaev is a hero," he says. "He personifies everything irrepressible, elemental, furious and protesting that has built up among the peasantry over a long period of time" (68-69, emphasis mine).

After some months, Klychkov recognizes that Chapaev has made progress ("he was already drawn to much that was reasonable and right consciously and not only instinctively" [298, emphasis mine]). These two qualities, the instinctive or spontaneous and the rational or conscious, again evoke Dostoevsky's Raskolnikov, with the polarity of positive/negative reversed. For Dostoevsky, it was the instinctively Russian (and orthodox) feelings of Raskolnikov that had to take the fore in order for him to reenter society; the nineteenth-century city, with its intellectual depravity, had corrupted the innocent young man and drawn him into intellectual errors. Dostoevsky's tortured intellectual convinces himself to commit a crime; his overly conscious man still does good instinctively but rejects that good through much of the novel with his rational, ideological mind. In the postrevolutionary context, consciousness and reason have become good, and instinct must be reined in.

Thus, while Chapaev's instinctual talents and impulses are not labeled as bad per se, the instinctual Chapaev must learn consciousness and rationality in order to become a proper Soviet hero. In examining the rhetorical strategies of Chapaev, Ronald Vroon has argued that "the tale of Chapaev may be read ... as a kind of allegory on the role of rhetoric in an ideological context." He writes, "For Furmanov, the word had to be harnessed, like Chapaev himself, in order to ensure ideological purity and, more importantly, the stability of the new political order." ${ }^{30}$

Chapaev was warmly received and became almost instantly beloved. Furmanov's contemporary Libedinsky celebrated the author as the "first in

30 Ronald Vroon, "Dmitry Furmanov's Chapaev and the Aesthetics of the Russian Avant-Garde," in Laboratory of Dreams: The Russian Avant-Garde and Cultural Experiment, ed. John E. Bowlt and Olga Matich (Stanford: Stanford University Press, 1996), 219-236, 236. 
our literature to show the heroic persona of Soviet man in his full glory." He adds, "He offered a model for a realistic portrayal of important civic events, he showed the newly born beauty of our society as it was reorganizing itself along revolutionary lines and rushing toward communism." ${ }^{31}$ That "rush" was portrayed in the novel as well. At one point as he muses on Chapaev's development, commissar Klychkov reminds the reader of just how volatile the situation of war can be. "But the elements," Klychkov warns, "the devil knows where they may go! We've had incidents [...] where there was just such a splendid commander, like Chapaev, and then suddenly he went and bumped off his commissar! ... Or you look and he's gone off to the whites with his 'elemental' division ... The workers, they're another thing entirely; they will never leave, not under any circumstances, that is, if they have consciously joined the struggle" (68).

Worrying that he himself might be "bumped off," Klychkov personalizes the much larger threat the Civil War posed for the Soviet state. War is indeed a "plastic juncture" with results that are seldom predictable. In unleashing the "elemental," the state had to control it. Heroism, as embodied in Chapaev, was the way the state could discipline what might otherwise be chaotic violence and turn it to its own purposes: beating back the Whites and offering a heroic model for the future.

When Maxim Gorky, the arbiter of official Soviet literary taste, wrote to Furmanov about his work, he offered measured praise. Furmanov's writing was "interesting and deeply instructive," but Gorky was not fully confident in Furmanov's creative abilities. In his letter to Furmanov, Gorky asserted, "You narrate like a witness, but do not portray like an artist." ${ }^{32}$

A witness, not an artist. Here was a fundamental problem for anyone who would turn the experience of war into fiction. To write without having been a witness would have been hollow, but to turn the testimony of witness into the material of art undoubtedly required some betrayal of that experience of witnessing. For the early years of Soviet literature-when readers burned for the "literature of fact," for the "sensation of life," for characters based in the revolutionary events through which they themselves had lived-the witness was enough. Furmanov immortalized his own "path to Bolshevism" in his memoirs of that name, but he incarnated his adolescent

31 Libedinsky, "Bol'shevik, voin,"183.

32 Isbakh, Furmanov, 254. 
anarchist spirit perhaps equally convincingly in the peasant leader Vasily Chapaev and then "harnessed" that spirit to his autobiographical political commissar. His characters and their Civil War struggles became iconic for the rest of the century.

\section{War on the Domestic Front in Gladkov's Cement}

Not long after the publication of Chapaev, Fyodor Gladkov penned his classic factory and production novel Cement. As mentioned earlier, the two novels have much in common, and Gladkov must certainly have noticed Furmanov's success with Chapaev as he was writing. We might see these two novels loosely as a paired set, providing for readers an account of heroism in the Civil War and then in the immediate aftermath of the war. Chapaev perished in a glorious cause, fully aware of that cause, in some ways the "easier" ending. In contrast, Gladkov grappled with the concept of postwar demobilization: Gleb Chumalov must rebuild his life after the destruction of war and in so doing make good on the promise that the war had made way for a better future. Chumalov embraces a slogan that originated in an 1895 story by Maxim Gorky: "In life there is always a place for feats." ${ }^{33}$ This oft-repeated quote is the origin of the rhetoric of podvig, of great feats, that played a vital role in Soviet literature and in everyday life. Gladkov's hero must apply the rhetoric of podvig to the quotidian task of restarting a factory.

Cement is the first Soviet attempt at an important subset of war literature: novels that explore the lives of soldiers returning to a society they neither participated in building nor really understand after their months or years away from it. The shift in landscape between the two novels is dramatic: while Vasily Chapaev rode the steppe on his dashing mount ("na likhom kone"), the

33 A version of this phrase-a favorite with such Socialist realist novelists as Boris Polevoi, the author of A Story of a Real Man (Povest' o nastoiashchem cheloveke, 1946, film version 1949)—-was uttered by the heroine of Gor'kii's 1895 story “The Old Woman Izergil," who uses it in describing a former Polish lover who had fought in the Greek War of Independence, against the Turks, merely because "he loved feats." The story reads, "Why should he care about the Greeks, if he is a Pole? Here's why: he loved feats. And when a person loves feats, he can always do them, and he finds opportunities. In life, you know, there is always room for feats. And people who don't find them for themselves, - they are simply lazy cowards, or they don't understand life, because if they did understand life, everyone would want to leave his mark on it. And then life would not consume people without a trace..." 
hero of Cement drags himself back from his Civil War duties to a world that no longer resembles his pre-war home. Nor does he find there the comradeship and sense of purpose of his wartime life, a common enough problem for soldiers returning from the adrenaline-soaked experience of war to the mundane business of civilian life.

In Cement, Gleb's struggles do not end when he arrives home from the war. Instead, he begins to fight on a new front: fighting the disarray of postwar life, the bourgeois-ification of his factory town, the bureaucratic obstacles to reconstruction, and the private and personal instincts of his former mates. In this sense, Cement stands as the first important attempt to portray Soviet society as constantly at war; it militarizes daily life in a way that would come to characterize the entire Soviet period.

The task presented in Gladkov's novel is a monumental one. Gleb must relaunch a factory after its destruction by the White Army, resurrect it from its ruined state (characterized as razrukha), and set it humming. The task is made more arduous because of continuing destructive action by partisan fighters, because of squabbles within the local Communist Party ranks and the disruptive purge of that party, because of a reluctance to help from all state organs above the factory workers and-perhaps most significantly-because of the absurdity of producing cement for a country where no one is building anything. More than anything, this task is a symbolic one: the city had a history of production, and to enter into a new era the factory needed to access its past. New ideas and new thoughts would be poured into the cement molds of old.

The novel is set somewhere in the southern Russian periphery, paralleling the site of Chapaev's regiment, which ranged across the vast steppes. The periphery, as Clark has noted, is the perfect space for novels focused on the ordinary characters who make up the Soviet people. She writes:

Socialist realist novels are generally set in the periphery. This is not just because it provides a pared-down microcosm for representing processes that take place in the greater arena of society at large, but also because the periphery is the space of the masses. ${ }^{34}$

34 Katerina Clark, "Socialist Realism and the Sacralizing of Space" in The Landscape of Stalinism: The Art and Ideology of Soviet Space, ed. Evgeny Dobrenko and Eric Naiman (Seattle: University of Washington Press, 2003), 3-18; 14. 
Having himself been exiled to the periphery in 1906, in the 1920s Gladkov found himself with just the right personal experience to write construction novels of and for the masses. The factory town of Cement appears to be modelled on Novorossiysk, the main Russian port on the Black Sea, where Gladkov lived for a time. Peripheral though it may be, this formerly bustling port is populated with thousands of workers, as well as a number of intellectuals and former members of the aristocracy. We are told that the factory once sold much of its cement abroad, but in the post-Civil War era, that market has become inaccessible.

Gladkov's construction novels were heralded in the early 1930s-in the midst of active discussions of the advent of a "socialist" realism-as constituting a specifically "proletarian realism." ${ }^{35}$ And while he would not have denied the "realism" ascribed to him, Gladkov saw his own work as belonging to the movement of revolutionary romanticism started by Maxim Gorky.

Gladkov's style includes the expansive use of metaphors and other prose embellishments. ${ }^{36}$ In discussing his own methods, Gladkov stressed that authors should never be afraid of romanticizing the hero, of highlighting the positive traits of the main character of a work. He aimed for what he called zhivuchost'-a "living quality" - in his characters, but that living quality included a "heroism" that he believed to be characteristic of the Soviet man (in his own words, "our man").

The significance of the protagonist of a fictional work, his "living quality" [zhivuchest'] for our history is defined by his typicality for his epoch, that is to say the power of the synthesis of the more characteristic qualities of that social environment which a given protagonist represents. ${ }^{37}$

In constructing his new Soviet novel, Gladkov took up a central metaphor straight out of Turgenev. From his bloody days in the Civil War, Gleb

35 A. Kemp-Welch, Stalin and the Literary Intelligentsia, 142. Gladkov was at the forefront of the Sovietization of Russian literature, one of seven named to the commission on union membership as the Union of Soviet Writers was being formed (Kemp-Welch, Stalin and the Literary Intelligentsia, 171).

36 As Robert Busch has commented, referring to the nineteenth-century Romantic writer Alexander Bestuzhev-Marlinsky, Gladkov tended "toward the Marlinskian principle of never putting simply what could be said with a flourish." Busch, "Making of a Classic," 357.

37 Fedor Gladkov, "Moia rabota nad 'Tsementom' (V poriadke samokritiki)," in Gladkov, Sobranie sochinenii v vos'mi tomakh, vol. 2 (Moscow: Gosizdatkhudlit, 1958), 421. 
Chumalov returns to the home he identifies as his "nest"- and finds that nest empty. ${ }^{38}$ This symbol of nineteenth-century family happiness-the nest-is a recurring metaphor throughout the novel, now a neutral concept, now tragic, now negative. Turgenev's cherished but often problematic "nest of the gentry" has received new life in a new stratum of society as Gladkov reinvents the old chronotope for new purposes in a new age. ${ }^{39}$

The settlement to which Gleb returns has the traditional but telling name of "Cozy Colony" ("Uyutnaya koloniya"). ${ }^{40}$ This image of the cozy home would have been welcome to the warrior returning from the peripatetic life of army camps and battles, but in the postwar era there is nothing cozy about this place. The conventional home Gleb left has been transformed and is empty both physically and psychologically. As the omniscient narrator describes it:

Now he was back in the home he had once left to go out into the empty night. [.. .] Now the nest was empty, and his wife Dasha, who had clung to him so desperately at the time of their parting, had not welcomed him as a wife should. (Cement, 6)

No welcoming expressions of love, no sexual reunion, indeed, no nuclear family to greet the returning war hero. Instead, Gleb finds an empty and sterile Soviet hearth. Dasha Chumalova has taken their child Nyura to the communal children's home to be raised by the state rather than her parents, and she herself has joined the Zhenotdel, the women's department, and prefers to live in a dormitory. Much to Gleb's disappointment after his three-year absence, she cannot stay and celebrate his homecoming but instead rushes off on a business trip for her new Soviet work.

The Chumalovs are not the only ones whose "nest" has been destroyed by the revolution, the ensuing chaos, and the new world order of post-Civil War life. Gleb's neighbors Motya and Savchuk have suffered as well. Motya mourns her losses, lamenting, "I had children-little boys—and was a decent happy

38 Unless otherwise specified, I am quoting from A. S. Arthur and C. Ashleigh, trans., Cement (New York: Frederick Ungar, 1980), 6.

39 On homes and "nests" throughout Russian literature, see Joost van Baak, The House in Russian Literature: A Mythopoetic Exploration (Amsterdam, New York: Rodopi, 2009).

40 Arthur and Ashleigh translate it as "Pleasant Colony" (Cement, 1), but uyut has the essential connotation of home and hearth. 
mother. Where are they now, Gleb? Why am I no longer a mother? I want a nest; like a hen, I want chicks. But they have perished ..." (Cement, 10). Her once cozy home is transformed into a raucous site of screeching and fighting, and the love she and her family shared has turned into animosity between the parents.

Remembering the past in conversation with her husband, Motya continues, "We had a rich nest, Savchuk . . . And our children were dear little starlings ... Let's weave a new nest, Savchuk [... ] I shall go along the highway to find other people's orphaned little chicks." ${ }^{41}$ Like Gorky's Nilovna, Motya is willing to take on any children she can find to reconstitute her "family." Thus one solution-offered rhetorically but never fulfilled-for this bereft mother hen was a socialist vision of family on a larger, societal scale. But unlike Nilovna, Motya is stuck in her old way of thinking and has not undergone revolutionary training; even if she could gather together orphaned chicks, the result would be another nuclear family or a private version of the state children's home, not a larger socialist family.

The family fire has been extinguished, and the hearth in Gleb's home has gone cold. In a chapter by that name ("The Cold Hearth"), Gleb finds his room to be "strange, uninhabitable and stifling." In former years his wife had met him when he returned home at night. "In those days it was cozy and cheerful in the room." Warm and inviting and filled with flowers that "signalled welcome to him [from the windowsill] like little flames," his home had been full of life and the laughter of his wife and daughter; the floor shone like a mirror, the bed was soft and white, and the table laden with fine-smelling platters of food. The samovar-the central image of prosperous prerevolutionary peasant life, which played such an important role in the stories of Chekhov, ${ }^{42}$ among others-was at a boil, and the tea set clattered merrily.

Now, in contrast, these memories of the past are painful, and Gleb feels nauseated thinking of "this abandoned and mildewed home. Where the mice have fouled there can be no rest. Where the cozy fire has died the stinking

41 Tsement, Krasnaia nov' [no. 1], I, ii. 74. The literal meaning and ornithological metaphors disappear in Arthur and Ashleigh's translation: "We had a decent home, Savchuk, and our children were such dear little things. Your blood and my blood. Let's make a new home, Savchuk. I can't bear it; I can't, Savchuk. I shall go along the highway to find homeless children" (Cement, 11).

42 I have in mind here especially "The Peasants" (1897), in which the samovar is confiscated for lack of tax payment, leaving the peasant home empty and bereft. 
vermin now swarm" (Cement, 26-27). All remnants of his former life have vanished, and what remains is a cold and dirty hearth in an empty, abandoned home.

The concept of the nest is larger than the individual home; for Gleb the family should be a microcosm of a larger social entity, the workers' collective. And here it is, the empty home echoes the empty factory, which rather than being a nest of activity is described as a "gigantic tomb, a place of desolation and destruction. ... Like a dead planet, the factory slept in these idle days" (Cement, 13, 14). Evoking cosmic scale, Gladkov emphasizes the barrenness of the empty factory, but with his verb "slept," he offers hope that someone-some hero or collection of heroes fighting on the economic front-can awaken this enterprise from its slumber and set it going again.

Finding both of his homes ruined, Gleb throws himself into the work of reviving the factory, even while he tries to understand the changed circumstances of his personal home front. ${ }^{43} \mathrm{He}$ realizes that he no longer has the rights of "a master" over his wife, Dasha, and cannot simply keep her with him, though he tries, saying, "Without you there is no warm comfortable home, and my bed will be cold and grow soiled" (Cement, 290). She leaves him anyway to go live with her friend and comrade Polina Mekhova.

The neglect of their small family leads to the death of their little daughter in her communal home. Gleb is devastated, but not so self-focused as to forget to make the analogy between his own personal situation and the situation at the cement factory:

Now everything was suddenly bare, oppressive and strange; this dwelling, the garden path, the little garden itself, and this wall which separated him from Dasha and which surrounded him like the wall of a prison. What was the good of the empty, musty room now? [...] Dasha was no longer there, and he was alone. Nurka had died. No Dasha. No Nurka. He was alone. A damnable life! It was like the crusher: it broke everything, destiny, habits, love. (Cement, 293)

43 In the 1958 version of the novel, Polya Mekhova teases Gleb that his trouble with Dasha must have come from trying to assert his conjugal rights. When he blushes in response, she says, "Oh you, men, men! . . . The domostroevshchina is still strong in you! . . Y You still lack the manliness to respect a woman ..." (Tsement 1958: 128). In the last chapter of this revised version, Dasha finds that "there was still too much of the old husband in him-an excessive desire for tenderness, and a torturous jealousy, and a persistent desire to nail her to the home nest" (Tsement 1958: 260). 
In the post-Civil War era, Gleb comes to realize, he must tackle the question of home and personal happiness in the same way that he is tirelessly putting the factory into order. In a moment of optimism, he says to Motya, "We'll build a new nest, Motya ... What's the big deal? The old nest must have been worthless ..." (Cement, 293). Taking the good-the idea of the nest-from the traditional ideal, Gleb wants to reinvent it and make it better for the future.

In Cement, as in Turgenev, the nest does not always have positive connotations. The exploiting Communist Shramm, in particular, is described as living in a "cozy little nest of his own" (shrammovo gnezdishko), filled "with fine upholstered furniture, fur rugs and carpets" (Cement, 234, 233), where he and his comrades nightly betray the ideals of the revolution, leaving food, drink, and cigarettes to be cleaned up later by the chambermaids at the House of Soviets. Old forms had to die, but one of the main conflicts in the second half of Cement centers around the fact that in the post-Civil War period, instead of the promised new life, fragments of the old are returning.

As Comrade Zhidky explains to a Georgian soldier who has been monitoring Shramm's disgraceful behavior:

We're going to be subjected to a dreadful trial, worse than civil war, ruin, famine and blockade. We're in the presence of a hidden foe who is not going to shoot us, but will spread before us all the charms and temptations of capitalist business [...] The obyvatel' is crawling out of the womb. ${ }^{44}$ He's beginning to get fat and re-incarnates himself in various forms. He is already weaving his nest in our ranks as well, and barricading himself firmly with revolutionary rhetoric and all kinds of red attributes of Bolshevik valour. ${ }^{45}$

The enemy within. Although the armed conflicts had waned, the thrust of the novel reminded readers of the need to remain on guard, to treat everyday life as a continuing battle-outside and even within the party.

If the warmth of the Turgenev-era nest is gone, and the Chekhovian samovar remains extinguished, new forms and metaphors are needed in a

44 Arthur and Ashleigh translate, "The petty trader is crawling out of his hole."

45 Cement, 237. Arthur and Ashleigh translate, "For instance, he's trying to install himself in our own ranks, behind a solid barricade of revolutionary phrases, with all the attributes of Bolshevik valour." 
new world. Dasha herself says as much in the last conversation she and Gleb have in the book:

It's not our fault, Gleb. The old life has perished and will not return. We must build up a new life. The time will come when we shall build ourselves new homes. Love will always be love, Gleb, but it requires a new form. Everything will come through and attain new forms, and then we shall know how to forge new links. (Cement, 308)

The war in Cement comes with casualties for Gleb and Dasha: their original domestic life, their nest of friends and associations, and most tragically their little daughter. Dasha has mourned the death of her daughter personally, but on a societal scale she recognizes that there must be individual sacrifices as the new society comes together.

As a representative of the new Soviet woman, Dasha does not even seem to resent Motya, a holdover from the past. In the first version of the novel, bird metaphors for the women characters abound: Motya is a "brood hen . . . waddling along like a fat duck." When Motya becomes pregnant again in an attempt to fill her family nest, she says to Dasha, "I'm going to have one every year now, if you want to know. I'm going to be a woman, while you're just a barren magpie." Such a metaphor-with Dasha merely making noise while Motya gets down to the business of reproduction-belies the omniscient narrator's empathy for women such as Dasha, who are setting out on a new and uncomfortable path. Motya revels in her traditional life and choices ("looking at [Gleb] sideways-like a hen. In her eyes-full of maternity and inward joy-tears sparked and quivered"), but she is hardly an ideal model for the Communist future. ${ }^{46}$ The metaphors of rebirth near the end of Cement are not limited to the maternal housewife Motya. In the last celebratory scene of the novel, Gleb is lionized as a hero of labor. He sees the cement factory on the eve of its return to life: "There it was, the factory-a bogatyr and a beauty! Not long ago it had been a corpse-a rubbish pile, a ruin, a rat's nest." And now the factory has been reborn-no

46 Cement, 292, 293. Her desires eerily foreshadow the kind of pronatalist policies that would be put in place in the Soviet Union and in Nazi Germany, leading to heroinemothers and the production of sons for the fatherland(s). See Hoffmann, Stalinist Values: The Cultural Norms of Soviet Modernity, 1917-1941 (Ithaca: Cornell University Press, 2003), 97-105. 
longer a rat's nest; Gleb portrays it as a folk hero, a real beauty capable of production. Gleb also gazes at the enormous crowd-twenty thousand people, with more still arriving-and sees them as "a living mountain: stones incarnated in flesh." ${ }^{47}$

But rebirth is not the only paradigm being accessed in this triumphant finale of Cement. Gladkov makes another comparison explicit with the banner flying below the railings of the balcony: "We Have Conquered on the Civil War Front. We Shall Conquer Also On The Economic Front". "On the labor front, the same self-denying hero as he was on the field of battle ..." That is how Gleb is introduced. Wanting to share the glory, Gleb reminds his listeners, "If I am a hero, then you are all heroes! [. . .] We are building up socialism, Comrades, and our proletarian culture. On to victory, Comrades!"48 The language here is the language of war: battlefields, fronts, victory. Wartime and postwar society are merging. Through Gleb, Gladkov demonstrated that war could be productive and not simply destructive.

Cement was welcomed by contemporary readers, who-living through the postwar chaos-must have found much that resonated with their own lives. ${ }^{49}$ Like Gleb, they too yearned for some hope that out of the rubble a new and better life might emerge. And like Gleb, they had to muster enormous amounts of energy in order to set about building that new life. This, after all, is always the promise of war and its aftermath-the need to build anew.

Certainly when it came out, Cement impressed perhaps the most important reader of all. Gorky wrote that Cement was "the first novel since the revolution to firmly seize and clearly illuminate the most important theme of the times-labor." ${ }^{50}$ As a former member of the Bolshevik underground,

47 Cement, 303. Arthur and Ashleigh's version reads, "Stones resuscitated into flesh." Edward Vavra, in his afterword to the English translation of Cement, makes an excellent case for interpreting Gleb as a Christ-like figure. He also makes a convincing argument for seeing Gleb and Dasha as two parts of one whole, with Gleb the "spontaneous" and Dasha the "conscious" hero. See Cement, 322.

48 Cement, 302, 310, 311.

49 They were precisely seeking those echoes. Some readers did not find them and reacted to Cement negatively: "There's no biography, and since there isn't, there's no understanding it either" (Dobrenko, Making of the State Reader, 130).

50 Gor'kii, Sobranie sochinenii, vol. 29, 438-439. 
Gladkov was able to portray his Communist figures convincingly, and his own experience as a volunteer in the Red Army surely helped him to chronicle that homecoming moment when a warrior from the battlefront must rethink his relationship to the world around him, beginning new battles on the home and economic fronts. The war hero becomes a hero of labor; this portrayal, in Gorky's view, answered the "social order" (sotsial'nyi zakaz) of the 1920s.

Critic Osip Brik was not as enthusiastic, but he did give Gladkov credit for understanding what Soviet literature needed-"simultaneously two diametrically opposed things: 'heroism and byt." Nonetheless, he insisted that Gladkov's efforts did not produce the desired combination:

If you read Cement quickly, it seems like the synthesis has been found, that Gladkov has managed to resolve the problem supposedly standing before Soviet literature. [. . .] In Cement there is everything that is recommended in the best cookbooks, but the feast is not edible, because the ingredients are not cooked; they are only pulverized into a literary paté. ${ }^{51}$

Readers paid no attention. In the 1920s Cement enjoyed an enormous popularity, perhaps because its problems were real-world problems. The novel offered a view into the myriad post-Civil War struggles returning soldiers faced. How to build a new society on the ruins of the old? A new literature for the proletariat, when many of the models had been written by authors of a nobility no longer welcome in Soviet Russia? New universal touchstones out of old national ideals that had once united a totally different stratum of Russians?

The author of Cement was trying to work these problems out in literary form. Readers surely didn't care that Gladkov's portrayals of heroics and byt did not belong in one novel, had not been properly cooked. For many Russians in the new Soviet Union in the years after the First World War, the Revolution, and the Civil War, trying to fashion any sort of future at all required not only enormous amounts of energy but also that leap of imagination that could bring byt and heroics together.

51 O. M. Brik, "Pochemu ponravilsia 'Tsement'?" Na literaturnom postu, 2 (1926): 30-32; reprinted in Epigony khudozhestva, Literatura fakta: pervyi sbornik materialov rabotnikov Lefa, ed. N. F. Chuzhak (Moscow: Federatsiia, 1929), 84-88. Quote on 87. 
But readers could not sustain that state indefinitely. Vasily Chapaev and Gleb Chumalov both stood as popular war heroes in the 1920s, but only one survived much beyond that. Gleb never found his way into the hearts of Russians the way Chapaev did. In the end, a cement factory did not produce the enduring hero that the Civil War had. That war, at least, ended in victory, one that Chapaev helped achieve. The bright better future promised in Cement stayed always in the future, and readers grew weary of reading about it.

\section{Chapaev for Children}

Among the first children to play at Chapaev was Boris Shorokhov.

He and his friends do so in Yury Libedinsky's 1930 novel Birth of a Hero. With other children in the schoolyard and home alone, dreaming on his bed, Boris plays his favorite imaginative game, world revolution: "And he himself, Boris Shorokhov, he is the head of all the revolutionary forces, he is like Trotsky in the Civil War, and all the soldiers of the Red Army know and love him, as Chapaev, Blyukher and Budyonny were known and loved by their divisions." ${ }^{2}$

The novel is fascinating for a number of reasons, including its exploration of different generations-Communists, Komsomol members, and Young Pioneers-and the way it tracks the relationships between ideology and sex, the individual and the collective, the state and the empire. By turning Boris into a pint-sized Chapaev, however, Libedinsky's novel tried to meld Furmanov's hero with Gladkov's tasks and delegate them to an adolescent. In this story, Libedinsky tried to demonstrate that in the process of tearing down the old Russian society and replacing it with a new Soviet society, new heroes could be born, a whole new blameless generation of them. And in case readers missed the point, those heroes would worship Chapaev.

Libedinsky's Boris Shorokhov is the son of two Old Bolsheviks, and he is the ideal Young Pioneer. Perceptive, thoughtful, and energetic, Borya shows remarkable initiative as well as concern for his fellow Soviet children. With Chapaev as his hero, indeed as more of a father figure than his own disappointing father, Boris throws himself into his duties at Young Pioneer camp. In the meantime, the elder Shorokhov, a Communist functionary in

52 Iurii Libedinskii, Rozhdenie geroia (Leningrad: Gosudarstvennoe izdatel'stvo khudozhestvennoi literatury, 1931), 117. 
charge of party discipline and maintaining moral clarity for Communists at the center-in Moscow-and the periphery-in far-off Turkestan-embarks upon an affair with the young sister of his deceased wife, losing his own moral compass and neglecting his duties and his children in the process.

The novel, set in 1924, deals in part with the messy sexual relationships and social flux of the post-Civil War era. Confused by their own assessments of stable "bourgeois" marriages as compared to the violence, alcohol abuse, and partner-swapping that seems to go on among their parents, these children who are themselves on the cusp of sexual awakening reject their parents in favor of another ideal entirely: a child-centered commune. A nursery, as it were, where new Soviet heroes can grow up free from the contamination of the old order.

It is worth pausing over this mise-en-scène. With his twelve-year-old protagonist, who is surrounded by a gaggle of orphaned, lost children whose parents are absent literally or figuratively, Libedinsky reminds us of the profound dislocation the period from 1914-1921 had wreaked upon Russian families and on Russian children in particular. A world inhabited by children in this way strikes us now as a literary conceit; for Libedinsky's generation it was a kind of reality. The unprecedented historical upheavals of this period had by 1922 left an estimated seven million abandoned and orphaned children, homeless and without supervision or support..$^{53}$ A quarter of a century later, novelist William Golding would use a world of children to explore a dystopian nightmare born of the Cold War in his 1954 novel Lord of the Flies. In the wake of the Russian Civil War, Libedinsky used it to build a better future. Caught in the midst of social problems that negatively affect his own life and the lives of his comrades, Boris rejects his childish dreams of revolutionary action in favor of a bold plan to create children's villages-a space he hopes adult problems will not be able to penetrate. These Communist children's villages present an ideal, contrasted in the novel to the organized Pioneer Camp and to the leaderless hordes of orphans (besprizorniki) who are the anarchic version of a true collective.

Those bands of orphans with their anarchistic tendency are presented as a negative alternative to the moral center of the novel, Boris Shorokhov,

53 See Alan Ball, And Now My Soul Is Hardened: Abandoned Children in Soviet Russia, 1918-1930 (Berkeley: University of California Press, 1996), 1. Ball describes the many reasons for the separation of families on 11-13 and elsewhere. 
the Chapaev of the next generation. The hero of Libedinsky's novel is born along with the Soviet country itself, and his struggles to find the right path are exemplary. The peasant military hero (uneducated and illiterate, with the spontaneity characteristic of an adolescent) is the perfect ideal for a twelveyear-old psyche, whose love of clarity and simplicity will mark the development of the Soviet novel for decades to come. The children who sought to establish their own Soviet "home" in Libedinsky's Birth of a Hero were the ones who went off to war against the Nazis, treasuring their affinity to Chapaev and priding themselves on being his comrades. 